\title{
Anaplastic transformation of an atypical intraventricular meningioma with metastases to the liver: case report
}

\author{
M. Garcia-Conde; H. Roldan-Delgado; D. Martel-Barth-Hansen y C. Manzano-Sanz*
}

Departments of Neurosurgery and Pathology*. Hospital Universitario de Canarias. Tenerife. Spain.

Summary

Objective. Malignant intraventricular meningiomas are very rare. To the best of our knowledge, only eleven cases have been reported thus far. Seven of them developed cerebrospinal fluid (CSF) metastases. We present herein the first case of a malignant intraventricular meningioma with extraneural metastases.

Clinical presentation. We report a 44 year-old-man with a history of progressive headache and disorientation. Magnetic resonance imaging (MRI) revealed a 5-cm homogeneously-enhancing mass in the right trigone.

Intervention. The lesion was totally resected via a parietooccipital transcortical approach. Histological examination demonstrated an atypical meningioma. Thereafter, the tumor recurred twice. At first recurrence, the tumor was completely removed again and external radiotherapy was administered. At surgery at second recurrence, the tumor was more aggressive, invading the brain parenchyma. Histological examination showed anaplastic meningioma. The patient was readmitted to hospital with fever and pain in right hypochondrium. Abdominal ultrasound examination disclosed multiple hypoechoic liver lesions. Biopsy was consistent with liver metastases of a malignant meningioma. The patient died of acute liver failure seven months after initial diagnosis.

Conclusion. Malignant intraventricular meningiomas are prone to recur and develop metastases, mainly through the CSF. Nevertheless, our case shows that extraneural metastases are also possible. Therefore, when systemic deterioration occurs in a patient with a malignant intraventricular meningioma, metastases to extraneural organs such as the liver must be ruled out.

KEY WORDS: Intraventricular malignant meningioma. Acute liver failure. Anaplastic. Extraneural dissemination. Intraventricular meningioma. Liver metastases.

Recibido: 7-01-09. Aceptado: 31-03-09
Transformación anaplásica de un meningioma atípico intraventricular con metástasis hepáticas: caso clínico

Resumen

Objetivos. Los meningiomas malignos intraventriculares son muy infrecuentes. En la bibliografía existente sólo se han descrito once casos hasta ahora. Siete de ellos desarrollaron metástasis a través del líquido cefalorraquídeo (LCR). Presentamos el primer caso de un meningioma maligno intraventricular con metástasis extraneurales.

Caso clínico. Paciente varón de 44 años de edad con una clínica de cefalea progresiva y desorientación. La resonancia magnética mostraba un proceso expansivo intracraneal en el trígono derecho con captación de contraste de forma homogénea.

Intervención. Se practicó una resección total de la lesión a través de un acceso transcortical. El análisis histológico mostró un meningioma atípico. A pesar de la resección total, el tumor recidivó otras dos veces. Después de la primera recidiva, el tumor fue extirpado nuevamente y el paciente recibió radioterapia externa. En la segunda recidiva, el tumor se comportó de forma más agresiva, invadiendo el parénquima cerebral. El análisis histológico mostraba un meningioma anaplásico. El paciente fue ingresado nuevamente por fiebre y dolor en el hipocondrio derecho. Una ecografía abdominal mostró múltiples lesiones hipoecogénicas hepáticas. La biopsia de dichas lesiones fue compatible con metástasis del meningioma maligno. El paciente falleció debido a una insuficiencia hepática aguda siete meses después del diagnóstico inicial.

Conclusiones. Los meningiomas malignos intraventriculares tienden a recurrir y producir metástasis, principalmente a través del LCR. Sin embargo, nuestro caso muestra que los meningioma malignos intraventriculares también pueden metastatizar fuera del sistema nervioso central, siendo el primer caso 

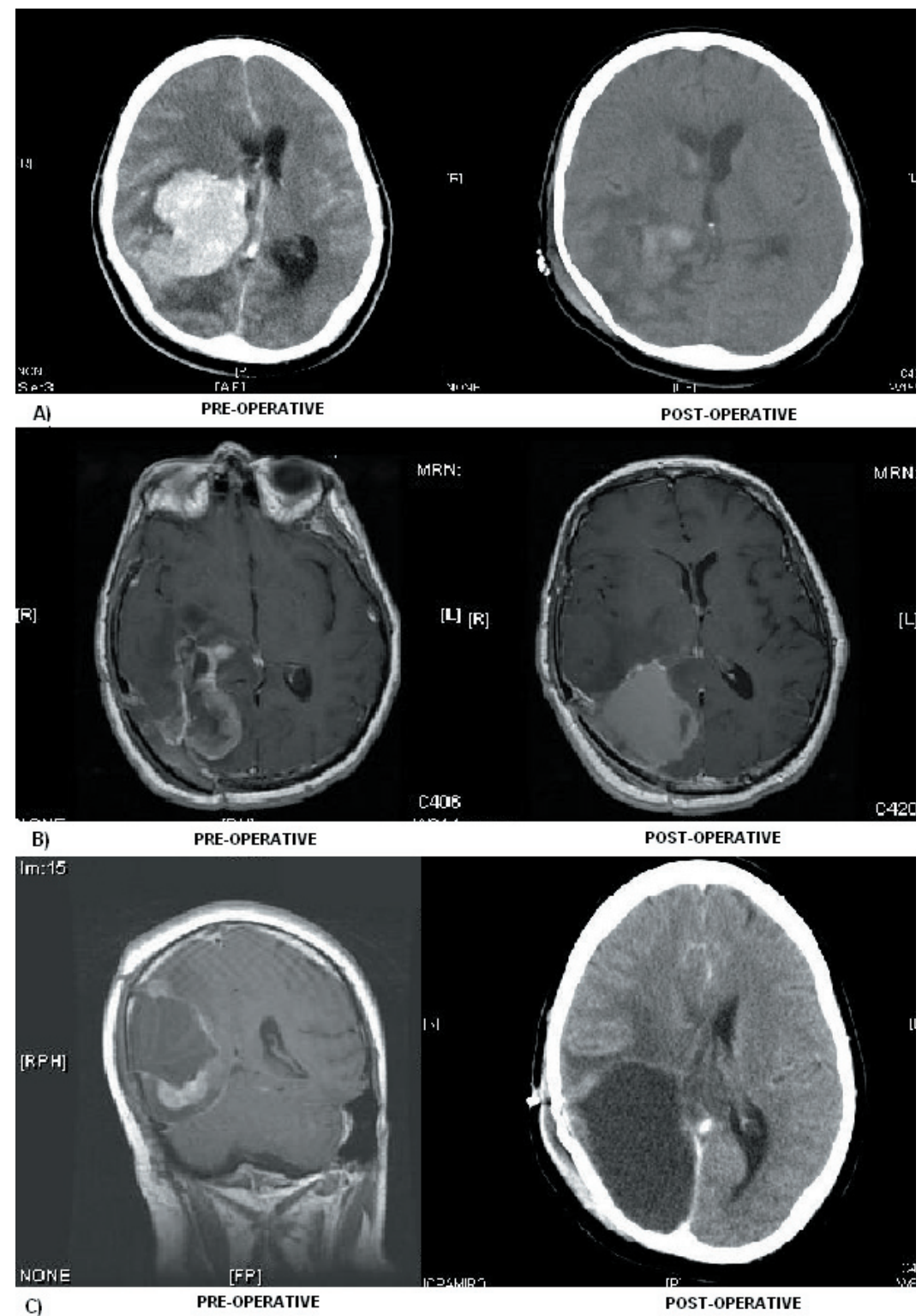

2009; 20: 541-549

Figure 1. Radiological evolution: 1. Enhanced CT-scan on admission showing a hyperdense lesion in the right trigone with important mass effect. Postop CTscan demonstrating total resection. 2. MRI T1WI with gadolinium enhancement disclosing first tumour recurrence. On enhanced postop MRI there was a hematoma at the surgical site without pathological enhancement. 3. At second recurrence, the MRI showed several tumoral nodes infiltrating the brain parenchyma. Postop CT-scan demonstrating the result after occipital lobectomy. descrito. Por lo tanto, cuando un deterioro sistémico ocurra en un paciente con un meningioma maligno intraventricular debería descartarse la posibilidad de metástasis extraneurales como sucedió en este caso.

PALABRAS CLAVE: Meningioma maligno intraventricular. Insuficiencia hepática aguda. Anaplásico. Diseminación extraneural. Meningioma intraventricular. Metástasis hepáticas.

\section{Introduction}

Intraventricular meningiomas are very rare neoplasms, and the majority of them are benign. Only 11 cases of malignant intraventricular meningiomas have been repor- ted so far. Most of the published cases already showed anaplastic histopathological features at the initial surgery, and the remaining evolved from benign to malignant types at recurrence.

The most frequent form of meningioma dissemination is hematogenous to extraneural organs. CSF metastases are rare. Nevertheless, in 7 out of 11 malignant intraventricular meningiomas reported in literature, tumor implants through CSF dissemination were described in various subarachnoid cisterns.

We present a case of an atypical intraventricular meningioma in the right trigone which, after two recurrences and a progressive histological transformation of the tumor into an anaplastic type, caused an acute liver failure as a result of multiple hepatic metastases, leading to 


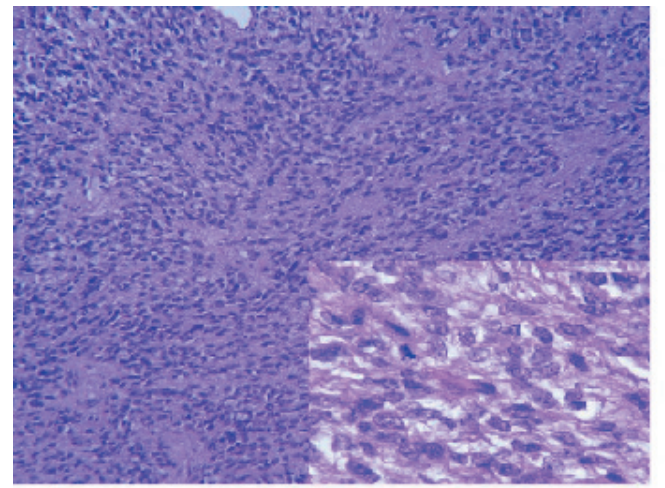

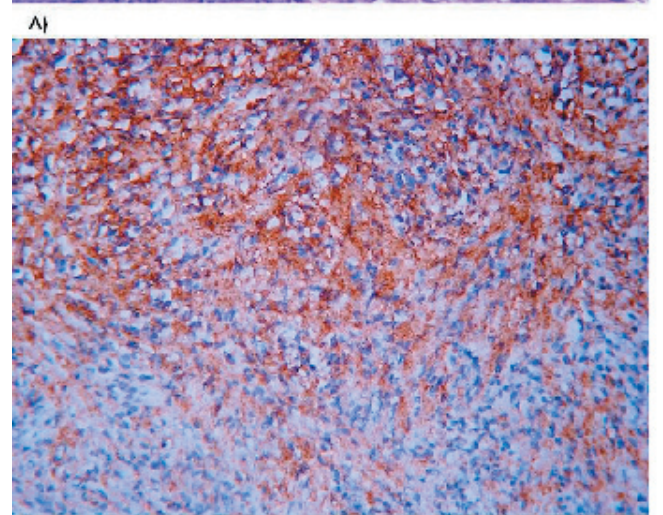

c)

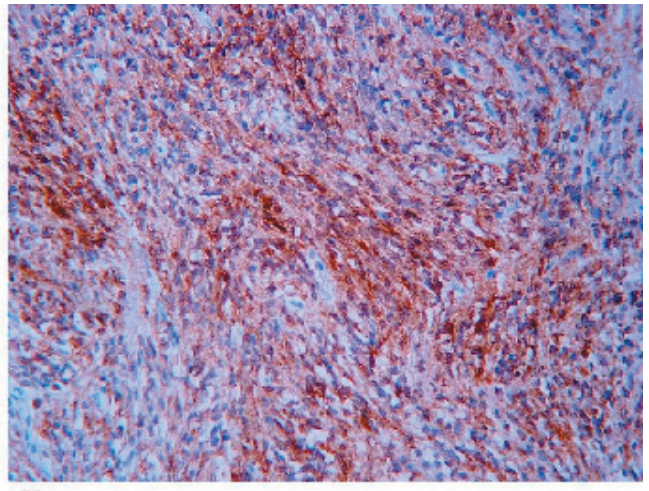

B)

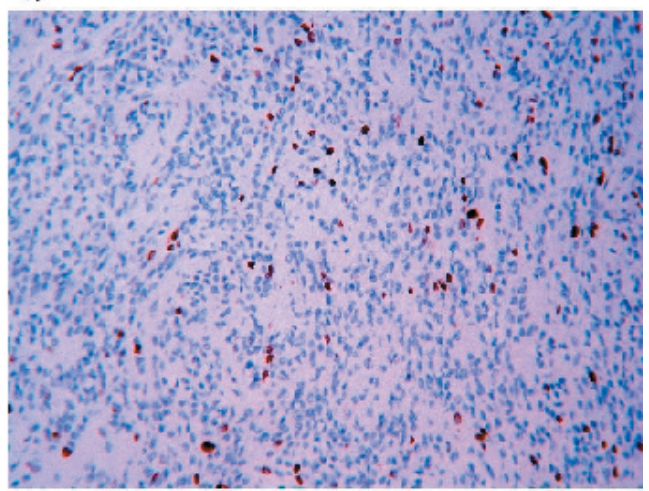

כ)

Figure 2. Photomicrographs of the first resection specimen. (A) Atypical meningioma with dense cellularity with detail at higher magnification. Hematoxylin and eosin stain (100x and 630x). (B) Immunoperoxidase stain was positive for EMA (200x) and (C) vimentin (200x). (D) Moderate Ki-67 proliferation index (100x).

patient's death.

To the best of our knowledge, this is the first case of extraneural metastases of an intraventricular malignant meningioma.

\section{Clinical case}

A 44-year-old man was admitted to hospital with headache, disorientation and two episodes of sphincter relaxation. No neurological deficits were present. CT and MRI showed a 5-cm lesion in the right trigone with intense homogenous contrast enhancement (Fig.1). Cerebral angiography revealed profuse vascularization proceeding from the right anterior choroidal artery.

Through a right transcortical parietooccipital approach, a Simpson's grade I (complete) resection was achieved (Fig.1). Histological examination disclosed a tumor with high cellularity, elongated cells and moderate mitotic activity ( $<10$ mitoses $/ 10 \mathrm{hpf}$, definited as $0.16 \mathrm{~mm} 2)$, a Ki-67 index of $10 \%$ and small areas of necrosis. The immunohistochemistry profile showed positivity for EMA and vimentin and negativity for GFAP, S-100 protein, CKAE3-AE1, muscular actin, desmin, HMB-45, Melan-A, CD-31 and CD-34. The tumor was categorized as atypical fibroblas- tic meningioma (WHO grade II) (Fig.2). Postoperatively, the patient was reoperated on twice for brain hematoma. At discharge, the patient had only left homonymous hemianopsia.

After two months, he was readmitted with intense headache and brain MRI revealed tumor recurrence in the right trigone (Fig. 1). He was reoperated on through the previous approach, with a new total resection. Histological analysis showed similar features to the previous tumor, but with an increase in the areas of necrosis and the mitotic activity (15-20 mitoses/10 hpf, definited as $0.16 \mathrm{~mm} 2$ ), suggesting a more aggressive type. The tumor was diagnosed as an atypical meningioma evolving to an anaplastic form (WHO grade III). Neuroaxis MRI was negative for spinal metastases. He was newly discharged with the same left homonymous hemianopsia and grade IV/V hemiparesis that did not preclude ambulation.

A month later, he received local external radiotherapy (5400 cGy in 27 fractions). Two months after last discharge, he was again readmitted with generalized tonic-clonic epileptic seizures. MRI revealed right temporooccipital tumor recurrence with mass effect and midline shift. An occipital lobectomy was carried out, as the tumor infiltrated the brain parenchyma (Fig. 1). Histological examination disclosed a 

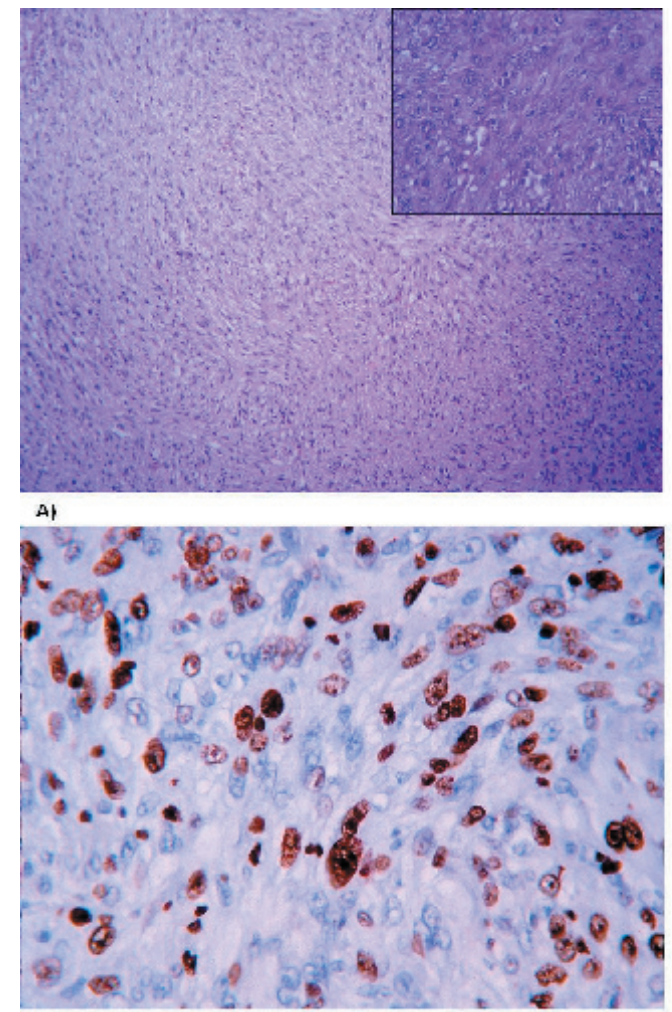

c)

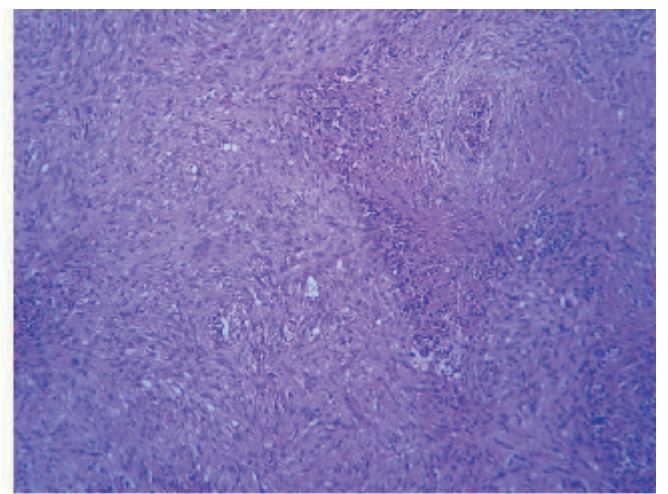

B)

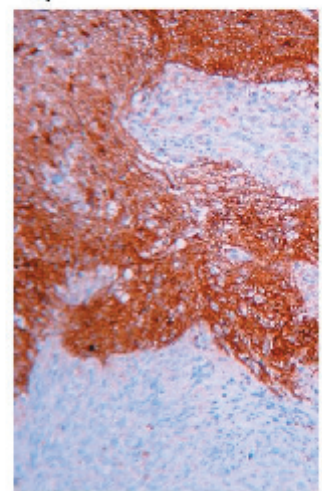

마

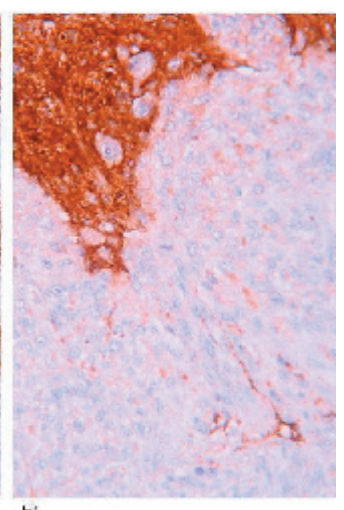

Figure 3. Photomicrographs of the second recurrence. (A) Anaplastic meningioma with sarcomatoid pattern and high mitotic activity, with detail at higher magnification. Hematoxylin and eosin stain (100x and 400x). (B) Geographic necrotic foci are evidenced. Hematoxylin and eosin stain (100x). (C) In this case, the tumor presents with a high Ki-67 proliferation index (400x), and (D) negativity for S-100 protein and (E) GFAP in contrast with the infiltrated brain parenchyma positivity (200x).

more anaplastic fusocellular sarcoma-like tumor with nuclear irregularities, wide foci of necrosis, high mitotic activity ( $>20$ mitoses $/ 10 \mathrm{hpf}$, definited as $\left.0.16 \mathrm{~mm}^{2}\right)$, and a $\mathrm{Ki}-67$ proliferation index as high as $50-60 \%$ in some areas. A wide infiltration of the brain parenchyma was also observed. All these features were consistent with the diagnosis of anaplastic meningioma (sarcoma-like, WHO grade III) (Fig. 3).

At discharge, the patient was fully alert but disoriented. He had left grade III/V hemiparesis that precluded autonomous ambulation.

Two days after discharge, he came back with fever and pain in the right hypochondrium. An abdominal ultrasound scan was done showing multiple hypoechoic hepatic lesions suggestive of abscesses or metastases. Transjugular liver biopsy demonstrated a solid neoplasm with atypical elongated cells and positive inmunoreactivity for EMA and vimentin. A diagnosis of hepatic metastasis of the anaplastic meningioma was therefore established (Fig.4).

Seven months after the initial diagnosis, the patient died of severe hepatic failure due to these metastases.

\section{Discussion}

Meningiomas comprise $14-19 \%$ of all intracranial tumors ${ }^{10}$. Of all meningiomas, those with intraventricular location(without an attachment of the meningioma to the dura) are a rare entity, comprising only a $0.5-5 \% \%^{5,24,28,32}$. Stratified by ages, intraventricular meningiomas occur more frequently in childhood, accounting for $15-19 \%$ of all intracranial meningiomas ${ }^{19}$.

The vast majority of intracranial meningiomas are benign. Malignant meningiomas are very uncommon $(1.8-7 \% \text { of all meningiomas })^{8,28}$. Nevertheless, there is a higher incidence of atypical or malignant forms in younger patients ${ }^{19,20,29}$. Therefore, a malignant intraventricular meningioma seldom occurs. To the best of our knowledge, only 11 cases have been described so $\operatorname{far}^{5,69,12,14,15,22,25,29,30,32}$ (Table 1). Ours seems to be the $12^{\text {th }}$.

Regarding location, malignant meningiomas show a similar distribution to the rest of intraventricular meningiomas, with predominance in the trigonal region ${ }^{18}$. Despite a higher incidence of intraventricular meningiomas and malignant histologies in children, only two cases of 

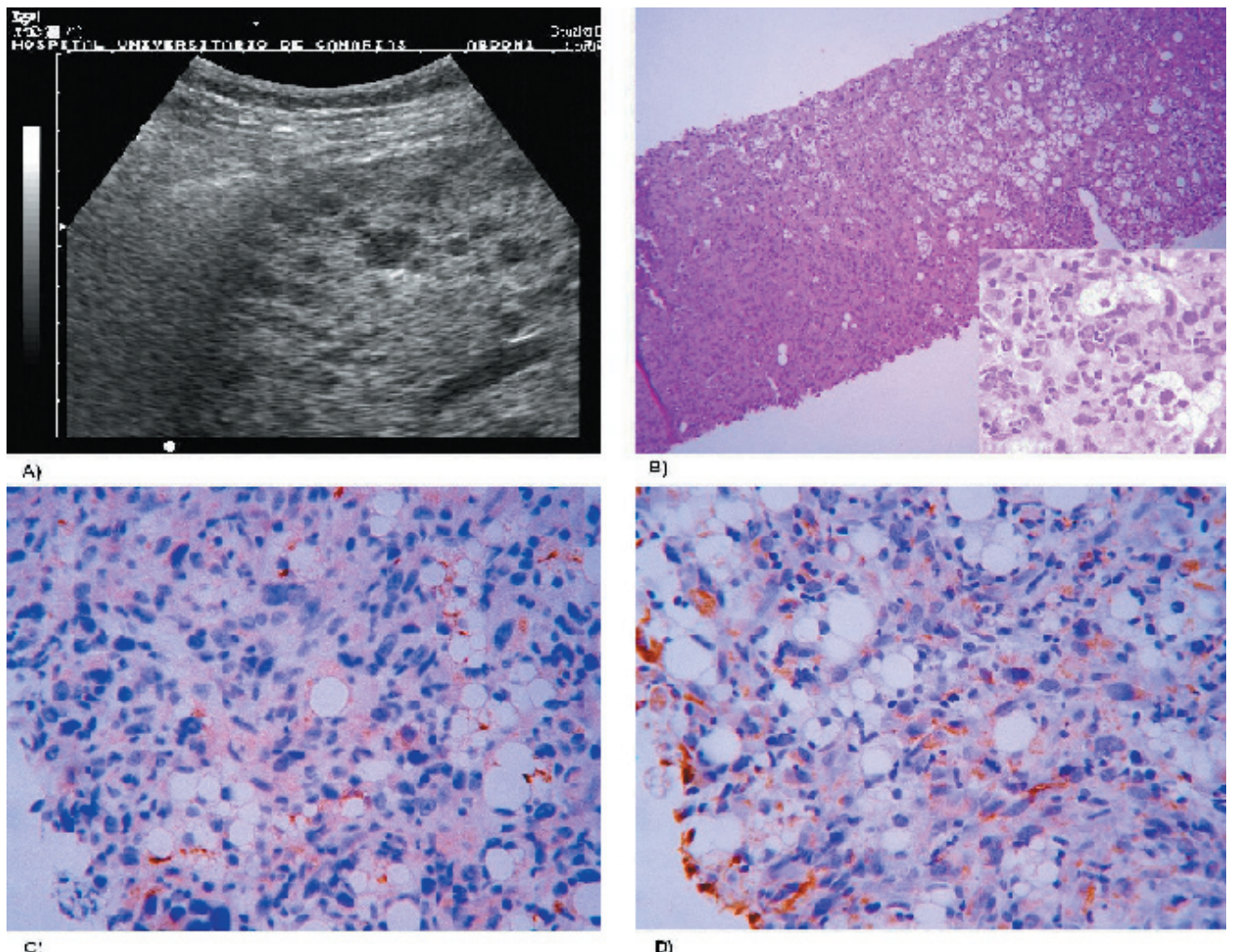

Figure 4. (A) Hepatic ultrasound examination showing hypoechoic lesions. (B) Hepatic cylinder with focal infiltration by meningioma. Elongated atypical cells at high magnification. Hematoxylin and eosin stain (100x and 630x). (C) Also positive for EMA (400x) and (D) vimentin (400x).

childhood intraventricular malignant meningiomas have been reported, the remaining ones occurring in patients older than 34 years of age. Distribution among sex is similar, being slightly more frequent among men, opposing to the overall tendency of meningiomas, which prevail in women twofold ${ }^{2,18,21}$.

MRI is the diagnostic test of choice to assess intraventricular tumors. Notwithstanding, a presumption diagnosis can only be established. The presence of a huge intraventricular mass with a heterogeneous signal both on T1- and T2-weighted MRI sequences, and the heterogeneous enhancement pattern after gadolinium administration due to necrotic tissue, should raise the suspicion of a malignant meningioma ${ }^{5,9,12}$. Benign intraventricular meningiomas, however, are more frequently iso-hypointense on T1-, iso-hyperintense on T2-weighted images with intense and homogeneous contrast enhancement ${ }^{16}$.

Differential diagnosis of intraventricular malignant meningiomas includes: 1) choroid plexus papillomas (in patients younger than 10 years of age); 2) low-grade astrocytomas; 3) ependymomas; 4) oligodendrogliomas (between 10 and 40 years of age); 5) metastases; 6) lymphomas; 7) benign meningiomas (after the fourth decade of life $)^{21}$.
From a histopathological point of view, intraventricular meningiomas can arise from the velum interpositum, the tela choroidea and the choroid plexus stroma ${ }^{5,29}$. Most of them are benign, and the most frequent histological types are fibroblastic or meningoteliomatous, although other forms, such as angiomatous, transitional or psammomatous, have been reported ${ }^{24}$. Among the malignant intraventricular meningiomas described (Table 1), primary anaplastic forms predominate, and only four cases evolved from atypical ${ }^{6}$ or benign patterns (transitional ${ }^{30}$ and fibroblastic ${ }^{22,25}$ ). In our case, the malignant meningioma derived secondarily from an atypical type, which is fairly uncommon.

In addition, like the rest of meningiomas, there is also a trend towards progressive evolution to malignancy when recurrences follow ${ }^{3}$. In two out of three atypical cases, the first recurrence was diagnosed before 4 month's time. In four initially benign meningiomas, recurrence diagnosis was never made before 52 week's time. Nevertheless, only two cases of recurrence out of 5 patients had an initial diagnosis of anaplastic meningioma.

The WHO 2000 Brain Tumor Classification establishes that anaplastic meningiomas correspond to WHO grade III tumors. "They exhibit obviously malignant citology resembling that of carcinoma, melanoma or sarcoma, or 


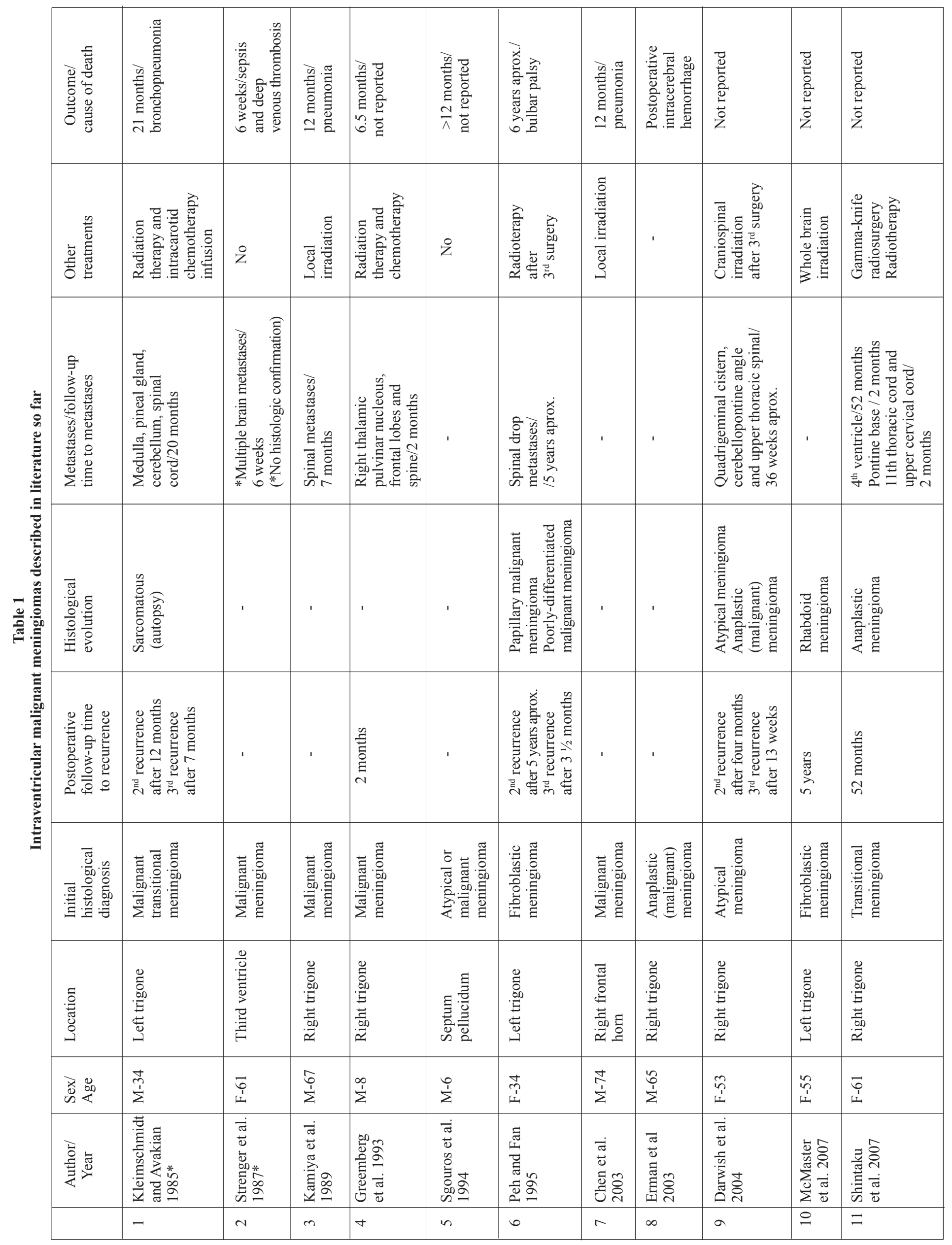


markedly elevated mitotic index (more than 20 mitoses/10 hpf) (defined as $0.16 \mathrm{~mm}^{2}$ )". They show an aggressive behaviour or a tendency to recur,are those which display. Brain parenchyma invasion is not a criterion to diagnose a meningioma as malignant (as this also happens in benign forms) although this fact may favour recurrences and metastases ${ }^{19}$. Inmunohistochemical tests are also of utmost importance, such as the Ki-67 proliferation index and positivity for EMA and vimentin, which are helpful to differentiate meningiomas from other central nervous system tumors, and atypical meningiomas from anaplastic types. These inmunohistochemical studies may also help to predict the recurrence rate ${ }^{26}$.

Anaplastic meningiomas have an overall recurrence rate of $50-78 \%$. These figures are also valid for intraventricular malignant meningiomas, in which 7 out of 12 described cases recurred (58\%). In four cases the recurrence was multiple.

The incidence of metastases among meningiomas is very low. Three different dissemination patterns have been described: hematogenous, lymphatic and via $\mathrm{CSF}^{8}$. When extraneural dissemination occur, meningiomas tend to metastatize most frequently to the lungs, followed by the liver, lymphatic nodes and bone ${ }^{13}$. Even though metastases of benign meningiomas have been reported ${ }^{26}$, the possibility of a meningioma to disseminate rises with histological aggressiveness $\mathrm{s}^{3,4,8}$. Malignant meningiomas have an incidence of metastases of approximately $43 \%{ }^{8}$.

The probability of benign meningiomas to disseminate and metastatize to extraneural sites is not presumably related to the primary intracranial location of the tumor, the type of surgery or the extent of surgical resection ${ }^{7}$. Nevertheless, surgical removal may increase the risk of iatrogenic metastases of meningiomas with atypical histologies ${ }^{1}$, and malignant meningiomas could even disseminate without previous surgery ${ }^{14}$.

Seeding through CSF does not seem to be related to surgery, given the great number of meningiomas operated on and the few reported cases of metastases via the $\mathrm{CSF}^{14,25}$. In fact, even though some cells could become loose during surgery and seed throughout the subarachnoidal space ${ }^{27,30}$, meningiomas metastatize more frequently outside the central nervous system.

Benign intraventricular meningiomas, despite being in contact with the CSF of the ventricles while growing, paradoxically tend to metastatize out of the central nervous system ${ }^{7,11}$, with only one case reported of metastasis through the $\mathrm{CSF}^{27}$.

On the other hand, the aggressiveness of an intraventricular meningioma is likely to be related to its probability to disseminate via the CSF, as in 7 out of the 11 cases were metastatic implants in different subarachnoidal locations (spinal cord, cerebellopontine angle, quadrigeminal cisterns, fourth ventricle, pontine base, etc.) were found. This trend may be due to the higher aggressiveness of these tumors and the ease of tumor cells to scatter through the subarachnoidal space ${ }^{17}$. Considering the tendency of these tumors to disseminate subarachnoidally, Darwish et al have recommended spinal diagnostic tests of intraventricular malignant meningiomas ${ }^{6}$.

In none of the intraventricular malignant meningiomas described so far extraneural metastases were found. Our case is the first one in which an intraventricular malignant meningioma disseminates outside the central nervous system. In our patient, multiple hepatic metastases were demonstrated. These implants could come from microembolisms of tumor cells derived from the arachnoid cap cells. These structures, placed near the arachnoid villi, are part of the anatomical boundaries of the blood-brain barrier ${ }^{5,10,31}$. This situation of the cap cells may have helped tumor cells to reach the blood stream through venous channels, and finally the liver through hematogenous or hematogenous/lymphatic pathways ${ }^{23,33}$. As a factor favouring extraneural dissemination, the multiple surgeries the patient went through (three tumor resections and two postsurgical hematomas) have probably played a role.

The prognosis of intraventricular malignant meningiomas varies depending on the initial histological diagnosis and the appearance of recurrences. In the majority of cases patients die before 12 months. If the anaplastic meningioma arises from a more benign type, longer survivals are achieved. Although several radiotherapy or even chemotherapy schemes have been used, the final prognosis seems unaltered.

Except for some cases in which patients died of conditions in direct relation with the tumor ${ }^{25}$, almost all the patients showed complications as the cause of death. In our case, the patient presented an acute liver failure secondary to the metastases. It is a very infrequent clinical picture, and death ensued despite intensive care treatment.

\section{Conclusions}

Intraventricular malignant meningiomas are very rare tumors. They slightly predominate among males and adults, though some cases have been described in childhood. Intraventricular meningiomas can show malignant features at the very beginning or evolve from more benign histological types. They can recur quickly, invade the brain parenchyma and tend to seed through the CSF to the subarachnoidal space. Hence a neuroaxis MRI is recommended in these patients. Aggressive surgical treatment (total resection) followed by radiotherapy is advocated. Despite this treatment scheme, the prognosis is dismal.

Our case adds the possibility of metastases outside the central nervous system in intraventricular malignant 
meningiomas. Therefore, attention must be payed in these patients to symptoms of systemic disease, and eventual extraneural dissemination has to be ruled out.

\section{References}

1. Akai, T., Shiraga, S., Iizuka, H., Kishibe, M., Kawakami, S., Ueda, Y.: Recurrent meningioma with metastasis to the skin incision--case report. Neurol Med Chir (Tokyo) 2004; 44: 600-602.

2. Bertalanffy, A., Roessler, K., Koperek, O. et al.: Intraventricular meningiomas: a report of 16 cases. Neurosurg Rev 2006; 29: 30-35.

3. Conrad, M.D., Schonauer, C., Pelissou-Guyotat, I., Morel, C., Madarassy, G., Deruty, R.: Recurrent lumbosacral metastases from intracranial meningioma. Report of a case and review of the literature. Acta Neurochir (Wien) 2001; 143 : 935-937.

4. Chamberlain, M.C., Glantz, M.J.: Cerebrospinal fluiddisseminated meningioma. Cancer 2005; 103: 1427-1430.

5. Chen, N.F., Lin, G.Y., Wang, Y.C., Leu, C.H., Kwan, P.C.: Intraventricular malignant meningioma: one case report. J Clin Neurosci 2003; 10: 616-620.

6. Darwish, B., Munro, I., Boet, R., Renaut, P., Abdelaal, A.S., MacFarlane, M.R.: Intraventricular meningioma with drop metastases and subgaleal metastatic nodule. J Clin Neurosci 2004; 11: 787-791.

7. Delgado-López, P.D., Martín-Velasco, V., CastillaDíez, J.M., et al.: Metastatic meningioma to the eleventh dorsal vertebral body: total en bloc spondylectomy. Case report and review of the literature. Neurocirugia 2006; 17 : 240-249.

8. Enam, S.A., Abdulrauf, S., Mehta, B., Malik, G.M., Mahmood, A.: Metastasis in meningioma. Acta Neurochir (Wien) 1996; 138: 1172-1177; discussion 1177-1178.

9. Erman, T., Gocer, A.I., Tuna, M., Erdogan, S., Zorludemir, S.: Malignant meningioma of the lateral ventricle. Case report. Neurosurg Focus 2003; 15: ECP2.

10. Figueroa, B.E., Quint, D.J., McKeever, P.E., Chandler, W.F.: Extracranial metastatic meningioma. Br J Radiol 1999; 72: 513-516.

11. Fulkerson, D.H., Horner, T.G., Hattab, E.M.: Histologically benign intraventricular meningioma with concurrent pulmonary metastasis: case report and review of the literature. Clin Neurol Neurosurg 2008; 110: 416-419.

12. Greenberg, S.B., Schneck, M.J., Faerber, E.N., Kanev, P.M.: Malignant meningioma in a child: CT and MR findings. AJR Am J Roentgenol 1993; 160: 1111-1112.

13. Kaminski, J.M., Movsas, B., King, E., et al.: Metastatic meningioma to the lung with multiple pleural metastases. Am J Clin Oncol 2001; 24: 579-582.

14. Kamiya, K., Inagawa, T., Nagasako, R.: Malignant intraventricular meningioma with spinal metastasis through the cerebrospinal fluid. Surg Neurol 1989; 32: 213-218.

15. Kleinschmidt-DeMasters, B.K., Avakian, J.J.: Wallenberg syndrome caused by CSF metastasis from malignant intraventricular meningioma. Clin Neuropathol 1985; 4: 214219.

16. Koeller, K.K., Sandberg, G.D.: From the archives of the AFIP. Cerebral intraventricular neoplasms: radiologic-pathologic correlation. Radiographics 2002; 22: 14731505 .

17. Lee, T.T., Landy, H.J.: Spinal metastases of malignant intracranial meningioma. Surg Neurol 1998; 50: 437-441.

18. Liu, M., Wei, Y., Liu, Y., Zhu, S., Li, X.: Intraventricular meninigiomas: a report of 25 cases. Neurosurg Rev 2006; 29 : 36-40.

19. Louis, D.N., Scheithauer, B.W., Budka, H., von Deimling, A., Kepes, J.J.: Maningiomas. In: Kleihues P,Cavenee WK (ed.). WHO Classification of Tumours Phatology and Genetics - Tumours of the Nervous System. Lyon; IARC Press, 2000; pp. 175-193.

20. Mahmood, A., Caccamo, D.V., Tomecek, F.J., Malik, G.M.: Atypical and malignant meningiomas: a clinicopathological review. Neurosurgery 1993; 33: 955-963.

21. Majos, C., Cucurella, G., Aguilera, C., Coll, S., Pons, L.C.: Intraventricular meningiomas: $\mathrm{MR}$ imaging and $\mathrm{MR}$ spectroscopic findings in two cases. AJNR Am J Neuroradiol 1999; 20: 882-885.

22. McMaster, J., Ng, T., Dexter, M.: Intraventricular rhabdoid meningioma. J Clin Neurosci 2007; 14: 672-675.

23. Nabeya, Y., Okazaki, Y., Watanabe, Y., et al.: Metastatic malignant meningioma of the liver with hypoglycemia: report of a case. Surg Today 1998; 28: 953-958.

24. Nakamura, M., Roser, F., Bundschuh, O., Vorkapic, P., Samii, M.: Intraventricular meningiomas: a review of 16 cases with reference to the literature. Surg Neurol 2003; 59: 491-503; discussion 503-494.

25. Peh, W.C., Fan, Y.W.: Case report: intraventricular meningioma with cerebellopontine angle and drop metastases. Br J Radiol 1995; 68: 428-430.

26. Pramesh, C.S., Saklani, A.P., Pantvaidya, G.H. et al.: Benign metastasizing meningioma. Jpn J Clin Oncol 2003; 33 : 86-88.

27. Ramakrishnamurthy, T.V., Murty, A.V., Purohit, A.K., Sundaram, C.: Benign meningioma metastasizing through CSF pathways: a case report and review of literature. Neurol India 2002; 50: 326-329.

28. Rohringer, M., Sutherland, G.R., Louw, D.F., Sima, A.A.: Incidence and clinicopathological features of meningioma. J Neurosurg 1989; 71: 665-672.

29. Sgouros, S., Walsh, A.R., Barber, P.: Intraventricular malignant meningioma in a 6-year-old child. Surg Neurol 1994; 42: 41-45.

30. Shintaku, M., Hashimoto, K., Okamoto, S.: Intraventricular meningioma with anaplastic transformation 
and metastasis via the cerebrospinal fluid. Neuropathology 2007; 27: 448-452.

31. Slavin, M.L.: Metastatic malignant meningioma. J Clin Neuroophthalmol 1989; 9: 55-59.

32. Strenger, S.W., Huang, Y.P., Sachdev, V.P.: Malignant meningioma within the third ventricle: a case report. Neurosurgery 1987; 20: 465-468.

33. Yoshida, D., Sugisaki, Y., Tamaki, T. et al.: Intracranial malignant meningioma with abdominal metastases associated with hypoglycemic shock: a case report. J Neurooncol 2000;
47: 51-58.

Garcia-Conde, M.; Roldan-Delgado, H.; Martel BarthHansen, D.; Manzano-Sanz, C.: Anaplastic transformation of an atypical intraventricular meningioma with metastases to the liver: case report. Neurocirugía 2009; 20: 541-549.

Correspondencia postal: Mario García-Conde. Hospital Universitario de Canarias. Servicio de Neurocirugía. Ofra s/n. La Laguna 38320 Santa Cruz de Tenerife. Spain. 